\title{
Proses corporate rebranding TVRI Jawa Barat menuju world class broadcaster
}

\author{
Herke Regitadika ${ }^{1}$, Hanny Hafiar ${ }^{2}$, Anwar Sani ${ }^{3}$ \\ 1,2,3 Universitas Padjadjaran, Bandung, Indonesia
}

\begin{abstract}
ABSTRAK
Rebranding merupakan hal yang tidak mudah karena melakukan perubahan posisi dan kesan masyarakat terhadap perusahaan memerlukan proses yang tepat. TVRI stasiun Jawa Barat memiliki strategi untuk menjadi world class broadcaster semenjak tahun 2017 namun belum tercapai. Strategi tersebut kembali diupayakan dengan melakukan berbagai cara agar membangun brand perusahaan salah satunya dengan melalui rebranding. Dengan demikian, penelitian ini bertujuan untuk mengetahui proses corporate rebanding dalam ketujuh tahapan yaitu triggering, analyzing and decision making, planning, preparing, launching, evaluating dan contiuning. Penelitian ini menggunakan metode deskriptif dengan jenis data kualitatif. Teknik pengumpulan data yang digunakan antara lain wawancara mendalam dengan ketujuh informan, dokumentasi dan studi pustaka. Teknik validitas data menggunakan triangulasi sumber. Hasil penelitian ini mengungkapkan bahwa rebranding ini diawali dengan mengidentifikasi masalah pada corporate strategy, competitive position dan external environment. Kemudian, dilakukan analyzing and decision making seperti market analysis, competitive analysis, competitor analysis dan analisis internal dengan analisis SWOT. Setelah membuat keputusan, keputusan tersebut ditindaklanjuti dengan planning seperti repositioning, renaming dan redesigning. Hasil perencanaan tersebut dilakukan persiapan dan pre-launching. Selanjutnya, launching dilakukan pada internal stakeholders dan external stakeholders. Setelah publikasi, hal yang dilakukan adalah mengevaluasi pelaksanaan pada awareness among stakeholders, customer surveys dan corporate image survey. Fase terakhir pada proses corporate rebranding ini yaitu mempertimbangkan keberlangsungan brand baru pada keseluruhan program dengan melihat pada for customers, for personnel dan management personnel. Simpulan dari penelitian ini adalah proses corporate rebranding yang dilaksanakan oleh TVRI stasiun Jawa Barat sudah baik, namun belum maksimal pada beberapa tahap seperti triggering, planning, preparing, evaluating dan continuing.
\end{abstract}

Kata-kata kunci: Televisi; penyiaran; merek; rebranding perusahaan; citra

\section{Corporate Rebranding Process of West Java TVRI to be World Class Broadcaster}

\begin{abstract}
Rebranding is not easy because changing the position and impression of the public on the company requires the right process. West Java station TVRI has a strategy to become a world class broadcaster since 2017 but has not yet been achieved. This strategy is being pursued again by using various ways to build the company's brand, one of which is through rebranding. Thus, this study aims to determine the corporate rebanding process in seven stages, namely triggering, analyzing and decision making, planning, preparing, launching, evaluating and controlling. This research uses descriptive method with qualitative data types. Data collection techniques used include in-depth interviews with the seven informants, documentation and literature study. The data validity technique used source triangulation. The results of this study reveal that this rebranding begins with identifying problems in corporate strategy, competitive position and the external environment. Then, analyzing and decision making such as market analysis, competitive analysis, competitor analysis and internal analysis are carried out using SWOT analysis. The decision is followed up with planning such as repositioning, renaming and redesigning. The results of the planning were carried out for preparation and pre-launching. Furthermore, the launching is carried out to internal stakeholders and external stakeholders. After publication, then evaluating the implementation of awareness among stakeholders, customer surveys and corporate image surveys. The final phase in the corporate rebranding process is to consider the continuity of the new brand in the entire program by looking at customers, for personnel and management personnel. The research conclusion is that the corporate rebranding process carried out by West Java station TVRI is already good, but it has not been maximized at several stages such as triggering, planning, preparing, evaluating and continuing.
\end{abstract}

Keywords: Television; broadcasting; brand; corporate rebranding; image

Korespondensi: Herke Regitadika S.I.Kom. Universitas Padjadjaran. Jalan raya Bandung-Sumedang KM. 21 Jatinangor 45363. Email: herkeregitadika@gmail.com 


\section{PENDAHULUAN}

Televisi merupakan media yang sangat berpengaruh dalam perkembangan teknologi informasi di seluruh dunia. Di Indonesia, Televisi Republik Indonesia (TVRI) hadir menjadi televisi pertama yang siarannya dapat dijangkau hampir seluruh rakyat Indonesia hingga kini. Seiring berjalannya waktu, stasiun televisi kini terus berkembang hingga bermunculannya stasiun televisi baru seperti NET TV, TRANS TV, GLOBAL TV, RCTI, dsb. Televisi kini mengalami banyak perubahan, televisi swasta yang memiliki kepentingan berbeda dengan televisi nasional membuat mereka lebih mudah mengembangkan eksistensinya. Televisi Swasta lebih disukai masyarakat Indonesia dikarenakan mereka lebih bersifat menghibur dan tidak terlalu memperhatikan edukasi, sehingga tentu masyarakat lebih memilih menonton televisi swasta dibandingkan televisi nasional yang seakan-akan terus menerus bersifat serius.

Diakui Apni Jaya Putra selaku direktur program dan berita, TVRI kini tua secara SDM, teknologi dan penonton (Putra, 2018). Padahal, TVRI merupakan stasiun televisi pertama di Indonesia, dan begitu booming-nya di zaman tersebut hingga terdengar ke berbagai macam negara di Asia. Keleluasaan penonton dalam menikmati tayangan televisi tersebutlah yang memberikan banyak warna baru serta perbedaan dari masing-masing saluran televisi, dari mulai perbedaan kualitas siaran, segi operasional, hingga kejernihan layar membuat para penikmat televisi tidak mau berkutat dalam satu stasiun televisi. Selain televisi, kini masyarakat mendapatkan informasi lebih mudah melalui media digital. Fenomena ini turut didukung oleh hasil riset dimana saat ini sudah terjadi perubahan dalam pola menonton TV terutama bagi generasi millenial yang sudah jarang duduk berjam-jam dihadapan layar TV untuk mengikuti sebuah acara. (Aprilia, Hafiar, \& Subekti, 2020)

Dalam penelitian lainnya yaitu survei Nielsen Consumer Media View (CMV), survei tersebut menunjukkan bahwa televisi masih menjadi media utama bagi masyarakat Indonesia dengan penetrasi televisi mencapai 96 persen. Di urutan kedua terdapat media luar ruang dengan penetrasi 53 persen, internet (44 persen), dan di posisi ketiga radio (37 persen). Namun, temuan yang menarik adalah keberadaan internet sebagai media dengan tingkat penetrasi cukup tinggi mengindikasikan bahwa masyarakat Indonesia semakin gemar mengakses berbagai konten melalui media digital. Padahal dalam lima tahun lalu (2012), penetrasi internet baru mencapai 26 persen (Nielson Indonesia, 2017). Sebagai media yang paling utama dikonsumsi oleh masyarakat dan terus berkembangnya media digital, berbagai stasiun televisi kini terus 
berinovasi untuk menyesuaikan diri dengan kebutuhan dan keinginan masyarakat.

TVRI kini telah mengudara lebih dari 56 tahun, televisi pertama di Indonesia ini tidak ingin lagi disebut ketinggalan zaman. Melalui kepemimpinan direksi periode 2017-2022 direktur utama TVRI, Helmi Yahya berupaya untuk mengubah citra TVRI menjadi lebih kekinian dan modern salah satunya dengan meluncurkan logo baru sebagai identitas baru atau rebranding. Dengan rebranding tersebut juga diharapkan dapat menjadi sekaligus perubahan dalam budaya perusahaan (corporate culture) menjadi spirit dan semangat baru. Rebranding TVRI sendiri memiliki tujuan yaitu bukan hanya sekedar mengganti logo tetapi juga dengan perkembangan misi TVRI ke depan untuk menjadi "World Class Public Broadcaster". Tujuan ini tentu menjadikan adanya desakan TVRI pusat pada seluruh TVRI daerah di Indonesia termasuk TVRI stasiun Jawa Barat untuk mendukung TVRI dalam mencapai visi tersebut. Hal ini juga tergambarkan dengan wujud lingkaran penyambung dunia elemen visual TVRI yang mengartikan satu siaran, satu suara, satu Indonesia untuk dunia. TVRI Stasiun Jawa Barat adalah bagian yang tak bisa terpisahkan dari TVRI Nasional secara keseluruhan. Masyarakat Jawa Barat diharapkan merasa memiliki dan mencintai TVRI Jawa Barat melalui program-program yang mengangkat kearifan lokal. TVRI stasiun Jawa Barat berperan untuk membawa kebanggaan Indonesia melalui konten lokalnya.

"World class broadcasting itu kan dicanangkan oleh TVRI pusat, ya walaupun kita ada TVRI pusat ada TVRI cabang semuanya ya sama karena tidak mungkin terpisah sendiri untuk mencapai visi itu. TVRI stasiun Jawa Barat Jabar semacam cabang nasional untuk wilayah provinsi Jawa Barat jadi untuk rebranding ya harus menyeluruh baik kantor pusat maupun daerah. Tentang World Class Broadcasting TVRI Jabar memiliki peran tersendiri adanya di Jawa Barat dengan support untuk mengangkat konten lokal sebagai upaya untuk mendukung world class broadcasting itu" (Herman, Wawancara Pra Survei, 2019).

TVRI stasiun Jawa Barat yang ingin mencapai internasionalisasi ini selaras dengan penelitian berjudul "International broadcasting as a tool of international diplomacy" yang mengungkapkan bahwa Penyiaran internasional sendiri dapat diartikan sebagai penyiaran melintasi batas negara ke luar negeri daripada penonton domestik. Penyebaran pesan dilakukan dengan sengaja kepada audiens di luar batas wilayah organisasi penyiaran (Vincent, 2016). Rebranding memang bukanlah hal yang baru dalam dunia pertelevisian. Namun, keberadaan televisi dengan karakteristik lokal yang menceriminkan internasionalisasi bukanlah sebuah hal yang biasa. Pada dasarnya, program standar dari media penyiaran publik adalah dengan menyiarkan program internal negaranya sekitar $60 \%$ perharinya, waktu tersebut juga 
dialokasikan untuk periklanan dalam dunia bisnis (maksimal 15\%) dan periklanan sosial (minimal 30\%) dari keseluruhan durasi (Masduki, 2017). Keberagaman tradisi lokal pada setiap tayangan masing-masing stasiun daerah membuat rebranding ini semakin menarik. TVRI stasiun Jawa Barat memiliki karakteristik kearifan lokal dengan seni dan budaya sunda yang tentu berbeda dengan TVRI stasiun Jawa Tengah dengan kearifan lokal Jawanya. Apabila konten dari TVRI stasiun Jawa Barat dapat dikatakan menarik, maka akan diakomodir TVRI pusat untuk disharing dengan TV negara lain. Hal ini memang sesuai dengan maksud Indikator keberhasilan menjadi world class broadcaster sendiri yaitu sudah dikenal dunia. Dalam hal akses, program siaran sudah bisa digunakan melalui media digital yang bisa diakses di berbagai negara. Namun sayangnya, program dari TVRI stasiun Jawa Barat belum ada yang sudah diakui dunia. TVRI pusat sendiri sudah melakukan proses untuk saling tukar program dengan TV negara lain.

"Indikator keberhasilan dari world class broadcasting itu ya kita udah dikenal dunia, TVRI sudah proses untuk saling tukar program dengan TV negara lain, kerjasama kita untuk mengambil liga inggris salah satunya tapi kalau program TVRI stasiun Jawa Barat sendiri belum ada yang mendunia, mendunia dalam arti sudah diakui oleh dunia belum kalau aksesnya sudah karena bisa pake internet." (Herman, Wawancara Pra Survei, 2019)

TVRI adalah media layanan publik
Indonesia yang terintegrasi di berbagai platform dengan hiburan yang mengangkat nilai, kebudayaan \& keberagaman yang membanggakan Indonesia. Namun, konten hiburan inilah yang menjadi kelemahan TVRI stasiun Jawa Barat baik setelah rebranding. Melalui hasil penelitian yang dilakukan oleh KPI pada tahun 2018, TVRI stasiun Jawa Barat dapat mengetahui indeks kualitas program yang ada di TVRI antara lain anak, wisata, budaya, religi, talkshow, berita dan variety show. Dari enam kategori program, ada lima program yang telah mencapai indeks kualitas program, indeks tertinggi adalah program anak 3,47 sementara indeks terendahnya yakni variety show 2,94. Begitu pula halnya pada indeks KPI 2019, TVRI stasiun Jawa Barat masih memiliki kelemahan pada bidang entertain. Oleh sebab itu, TVRI stasiun Jawa Barat juga dirasa perlu memaksimalkan konten hiburan.

"TVRI ini sudah diteliti oleh KPI bukan pesanan TVRI tetapi kebutuhan dia untuk meneliti program yang ada di TV Indonesia termasuk TVRI cabang untuk mengetahui standar. Hasil penelitian itu bekerjasama dengan perguruan tinggi di 11 kota di Indonesia termasuk Unpad di Jawa Barat. Di berbagai acara selain entartain, berita, acara budaya, acara religi, anak-anak, TVRI itu kan nomor 1 atau 2 yang menunjukkan kualitas. Kita sudah dipercaya publik tapi memang dihiburan harus diakui kita masih kurang, sekarangun masih dirasa lemah" (Herman, Wawancara Pra Survei, 2019).

Secara yuridis, fungsi penyiaran sebagai kegiatan komunikasi massa memiliki fungsi 
sebagai media informasi, pendidikan, hiburan yang sehat, kontrol dan perekat sosial (Panuju, 2017). Hal ini mengindikasikan bahwa selain berbanding terbalik dengan buku panduan identitas rebranding yang dimiliki, optimalisasi pada fungsi media massa yang dijalankan belum optimal karena belum memiliki kualitas yang baik berdasarkan survei indeks KPI pada bidang hiburan. Permasalahan internasionalisasi dengan membawa kebanggaan Indonesia melalui konten lokal Jawa Barat yang belum tercapai ini searah dengan proses rebranding yang belum dilakukan secara optimal. Hal ini tercermin pada belum dilakukannya change in ownership structure, restructuring, pretest for launching, evaluasi keseluruhan dan pertimbangan kelanjutan dari setiap proses berdasarkan hasil evaluasi pada beberapa point. Adanya televisi lokal erat kaitannya dengan UU No.32 tahun 2002 tentang penyiaran, pasal

31. Upaya Rebranding TVRI stasiun Jawa Barat diharapkan dapat menghidupkan dan mengembangkan aspek moralitas, kreativitas dan budi pekerti dalam payung kearifan lokal, (Sholihat, Perbawasari, \& Lukman, 2018).

Berdasarkan pemaparan diatas, peneliti melihat bahwa TVRI stasiun Jawa Barat kurang memperhatikan faktor-faktor yang dapat mendukung TVRI sebagai "world class broadcaster" sesuai dengan intruksi pusat. Hal ini memang hal yang tidak mudah dan sangat penting dilakukan oleh TVRI stasiun Jawa Barat untuk meriset terlebih dahulu agar TVRI stasiun Jawa Barat dapat membawa kebanggaan Indonesia di mata dunia. Oleh karena itu, peneliti akan menggunakan konsep proses corporate rebranding menurut Juntenen karena dalam penelitiannya yang berjudul "corporate rebranding as a process" dijelaskan bahwa faktor pendorong atau triggering dalam proses corporate rebanding salah satunya adalah untuk mencapai internasionalisasi. Proses corporate rebranding ini dilakukan melalui 7 tahap yaitu triggering, analyzing and decision making, planning, preparing, launching, evaluating dan continuing. Masalah ini belum lama terjadi sehingga masih dapat menjadi bahan yang masih hangat untuk diteliti. Peneliti akan berfokus pada proses corporate rebranding yang dilakukan TVRI Jawa Barat sebagai salah satu TV Daerah yang melakukan proses rebranding TVRI Nasional. Peneliti ingin meneliti bagaimana usaha TVRI stasiun Jawa Barat dalam mencapai "world class broadcaster" melalui rebranding.

\section{METODE PENELITIAN}

Penelitian ini menggunakan pendekatan kualitatif. Creswell mendefinisikan penelitian kualitatif sebagai pendekatan atau penelusuran untuk mengeksplorasi dan memahami suatu gejala sentral (Setiawan, 2010). Sedangkan 
untuk metode penelitian pada penelitian ini menggunakan metode deskriptif. Penelitian deskriptif adalah penelitian yang berusaha mendeskripsikan suatu gejala, peristiwa, kejadian yang terjadi saat sekarang. Melalui penelitian deskriptif, peneliti berusaha mendeskripsikan peristiwa dan kejadian yang menjadi pusat perhatian tanpa memberikan perlakuan khusus terhadap peristiwa tersebut. Variabel yang diteliti bisa tunggal (satu variabel) bisa juga lebih dari satu variabel (Noor, 2016).

Subjek penelitian ini adalah pihak-pihak yang terlibat dalam proses corporate rebranding LPP TVRI stasiun Jawa Barat. Sedangkan, objek penelitian ini adalah proses corporate rebranding LPP TVRI stasiun Jawa Barat sebagai upaya menjadi world class broadcaster. Penentuan informan pada penelitian ini dilakukan dengan teknik pusposive sampling, dimana pemilihan dilakukan secara sengaja berdasarkan kriteria yang telah ditentukan dan ditetapkan. Dari pertimbangan yang sudah ditentukan maka informan dalam penelitian ini adalah tim rebranding yaitu Herman, SE selaku kepala bidang berita dan ketua tim rebranding TVRI stasiun Jawa Barat, Muhammad Sanif SE., MM. selaku kepala bidang program dan pengembangan usaha, Drs. Kuswandi M,Si. selaku kepala sub bagian SDM, Pavo Eko Wilyarto R. selaku teknisi studio dan IT, Immanuel Adityo H. S. selaku divisi IT, Jarot Jantu Nusantara selaku teknisi transmisi dan editor, Encep Suryana S. H, MM. selaku staff bidang berita dan penyiar TVRI stasiun Jawa Barat. Peneliti menggunakan teknik pengumpulan data dengan observasi atau pengamatan, wawancara mendalam/ depth interview dan studi kepustakaan. Pada penelitian ini, peneliti menggunakan model Miles dan Huberman untuk analisis data. Menurut Miles dan Huberman ada tiga jenis kegiatan dalam analisis data reduksi data (data reduction), penyajian data (data display) dan penarikan dan pengujian kesimpulan (drawing and verifying conclusions) (Sugiyono, 2010). Teknik validitas data yang digunakan dalam penelitian ini adalah triangulasi sumber.

\section{HASIL DAN PEMBAHASAN}

Langkah pertama dari proses rebranding adalah mengidentifikasi dan mengatasi penyebabnya yang mengarah pada alasan untuk mengubah citra. Tahap triggering ini terdiri dari change in ownership structure, corporate strategy, competitive position dan external environment (Juntunen, Saraniemi, \& Jussila, 2010). Struktur kepemilikan (ownership structure) adalah struktur kepemilikan saham, yaitu perbandingan jumlah saham yang dimiliki oleh orang dalam (insiders) dengan jumlah saham yang dimiliki oleh investor (Franita, 2018). Perusahaan yang diambil dalam 
penelitian ini adalah kepemilikan publik.

Kepemilikan publik adalah kepemilikan yang dimiliki oleh publik (masyarakat) yang berarti persentase saham juga dimiliki oleh publik. Dalam hal ini, Implementasi proses rebranding yang dilakukan tidak melalui aspek perubahan kepemilikan. TVRI stasiun Jawa Barat hingga kini masih berdasarkan pada UU nomor 32 tahun 2002. Perubahan yang terjadi hanyalah pergantian direksi dan dewan pengawas yang menyebabkan terjadinya keputusan rebranding. Hal ini tentunya bertentangan dengan proses yang seharusnya dilakukan menurut Juntunen sendiri. Dalam penelitian (Juntunen, Saraniemi, \& Jussila, 2010) yang berjudul "corporate rebranding as a process" dijelaskan bahwa perubahan kepemilikan bukan hanya dari kepemilikan personal menjadi kepemilikan publik namun juga dapat mengubah kepemilikan publik menjadi personal. Dengan tidak dilakukannya perubahan kepemilikan tersebut, maka Mergers dan Acqusisitions Spin-Offs, Private to Public Ownership, Sponsorship juga tidak dilakukan.

Proses corporate rebranding ini juga biasanya dilatarbelakangi dengan tujuan perusahaan. Menurutnya, tujuan dari rebranding sendiri biasanya terbagi menjadi 2 yaitu Corporate Strategy (Strategi Perusahaan) dan Competitive position (posisi kompetitif). Menurut (Juntunen, Saraniemi, \& Jussila,
2010), hal-hal yang menjadi penting dalam corporate strategy yaitu diversification and divestment serta Internationalization and localization. Dalam aspek diversification and divestment, TVRI stasiun Jawa Barat tidak melalui hal tersebut. Hal ini dikarenakan memang tidak adanya penambahan atau pengurangan produk ataupun jasa. Diversifikasi sendiri menurut Kotler adalah salah satu cara untuk meningkatkan kinerja bisnis yang ada dengan jalan mengidentifikasi peluang untuk menambah bisnis menarik yang tidak berkaitan dengan bisnis perusahaan saat ini (Kotler \& Keller, 2009). Berbanding terbalik dengan diversifikasi, divestment strategy merupakan penjualan bisnis yang ada oleh sebuah perusahaan (Madura, 2007). Namun, dalam hal ini TVRI stasiun Jawa Barat tidak melakukan diversifikasi maupun divestment.

Pada aspek internasionalisasi dan lokalisasi, TVRI stasiun Jawa Barat memiliki strategi yaitu menjadi world class broadcaster. Strategi ini telah dimiliki oleh TVRI stasiun Jawa Barat semenjak tahun 2017 namun belum tercapai. TVRI stasiun Jawa Barat memiliki peran untuk membawa kebanggaan Indonesia melalui konten lokal TVRI stasiun Jawa Barat. Salah satu visi yang diharapkan oleh banyak perusahaan memang biasanya memasuki pasar internasional yang pabila hal tersebut terjadi maka mengindikasikan bahwa perusahaan 
mengalami pertumbuhan dan perkembangan.

Belum tercapainya world class broadcaster yang diharapkan membuat TVRI stasiun Jawa Barat yang didukung oleh keputusan pusat berupaya untuk mencapai visi tersebut melalui rebranding. Namun sayangnya, strategi tersebut hingga kini belum tercapai karena indikator keberhasilan untuk menjadi world class broadcaster yaitu konten TVRI stasiun Jawa Barat diakui dunia, hingga kini belum diakui dunia. Hal ini ditambah lagi dengan survei indeks KPI yang menyatakan bahwa TVRI stasiun Jawa Barat memiliki kelemahan pada bidang hiburan. Padahal, untuk mencapai world class broadcaster tersebut juga disebutkan dalam buku panduan identitas bahwa TVRI adalah media layanan publik Indonesia yang terintegrasi di berbagai platform dengan hiburan yang mengangkat nilai, kebudayaan dan keberagaman yang membanggakan Indonesia.

Pada Competitive position, Penilaian posisi kompetitif (competitive position) adalah cara untuk menentukan posisi kompetitif dari masing-masing pasar perusahaan atau organisasi pada sektor lini produk, pelanggan atau kelompok pelanggan. Tujuan mengetahui posisi kompetitifadalah untuk mengetahui posisi kompetitif perusahaan guna memaksimalkan nilai perusahaan dengan pengembangan strategi (Kurniawa \& Budhi, 2017). Hal--hal yang perlu diperhatikan dalam Competitive Position ini yaitu Erosion of market position, Outdated Image dan Reputation problems (Juntunen, Saraniemi, \& Jussila, 2010).

Erosion of market yang dimiliki oleh TVRI stasiun Jawa Barat mengacu pada hasil penelitian nielson. Penelitian Nielson tersebut menunjukkan bahwa TVRI stasiun Jawa Barat tidak pernah masuk dalam 10 besar dan hanya mendapatkan nilai 0 koma. Kurangnya penilaian dalam hasil penelitian tersebut juga selaras dengan Outdated image yang dimiliki oleh TVRI stasiun Jawa Barat. Lembaga penyiaran publik ini juga dirasa kuno atau lawas. Hal ini dapat terlihat dari tayangan program yang disiarkan dan logo yang dimiliki. Image atau citra pada dasarnya didefinisikan sebagai $a$ picture of mind yaitu suatu gambaran yang ada di dalam benak seseorang.

Hampir sama dengan image, reputasi adalah tujuan sekaligus merupakan prestasi yang hendak dicapai bagi perusahaan. Reputasi merupakan titipan kepercayaan dari masyarakat. Dalam hal reputasi, TVRI juga memiliki reputation problems yaitu berbedanya identitas yang dimiliki oleh masing-masing TVRI daerah. Hal ini dapat terlihat dari penyesuaian selera dalam penempatan dan penambahan teks pada logo yang dibebaskan pada TVRI stasiun masing-masing daerah. Identitas yang kurang jelas ini menimbulkan kebingungan pada persepsi masyarakat. 
Aspek terakhir dalam triggering menurut Juntunen adalah external environment. Menurut Juntunen, hal-hal yang perlu diperhatikan dalam external environment yaitu seperti legal obligation dan major crises or catastropes. Dalam hal legal obligation, TVRI berstatus lembaga penyiaran publik dirasa telah ditinggalkan. Masyarakat tidak lagi memiliki ketertarikan untuk menonton tayangan TVRI. Hadirnya media baru (new media) juga berpengaruh dalam otomatis menggeser peran 'media lama' atau tradisional. Oleh karena itu, televisi dan media tradisional lainnya kini mau tidak mau harus menghadapi new media. Sayangnya, meskipun digitalisasi yang dilakukan TVRI ini dilakukan sudah semenjak tahun 2008, media digital yang dimiliki oleh TVRI stasiun Jawa Barat masih dirasa belum maksimal dalam mengikuti perkembangan zaman. Media digital yang belum maksimal ini juga menyangkut dalam aspek major crises or catastrophes. Faktor-faktor tersebutlah yang mendorong terjadinya rebranding.

Tahap kedua setelah tahap triggering dalam proses corporate rebranding adalah tahap analyzing and decision making. Pada tahap ini, perusahaan menganalisis dan membuat keputusan mencakup menganalisis situasi saat ini. Menurut (Juntunen, Saraniemi, \& Jussila, 2010). Hal-hal yang current situation ini terdiri dari Market analysis, competitive analysis, competitor analysis, and recognizing possibilities. Analisis situasi merupakan langkah awal bagi sebuah organisasi atau perusahaan untuk bisa menganalisis hal-hal yang berhubungan atau akan menjadi suatu hubungan bagi organisasi atau perusahaan itu sendiri sebelum ke dalam pelaksanaan program atau acara (Utami, Dida, \& Prastowo, 2017). Berdasarkan hasil penelitian yang telah dilakukan oleh peneliti, TVRI stasiun Jawa Barat sudah melakukan analisis pasar. Namun, analisis pasar dilakukan melalui hasil kerjasama dengan berbagai pihak seperti kerjasama dengan puslikbang Jakarta, sharing dengan stakeholders, kerjasama penelitian dan berdasarkan hasil nielson, serta pemantauan hasil KPI pusat. Dari kerjasama tersebut dapat dilihat persepsi masyarakat terhadap TVRI termasuk TVRI stasiun Jawa Barat.

Analisis pasar ini juga dilakukan TVRI stasiun Jawa Barat berdasarkan dengan teori kedekatan sebagai acuan untuk melakukan keputusan pembuatan program. Kedekatan disini menurut pengamatan TVRI stasiun Jawa Barat adalah dengan melihat karakteristik masyarakat, luas pasar dan target audience. Selain market analysis, analisis lainnya yang perlu dilakukan adalah competitive analysis atau analisis persaingan. TVRI stasiun Jawa Barat tanpa disadari sudah mengidentifikasi lingkup pasarnya. Hal ini terlihat dari TVRI 
yang melihat manfaat serta komitmen yang berbeda dengan TV lainnya. Berdasarkan hasil wawancara, diketahui bahwa kualitas program acara TV swasta dirasa tidak sebaik TVRI karena TV swasta lebih mengejar komersil dibandingkan TVRI yang lebih melihat pada manfaat dan nilainya. Namun, kemasan TV swasta dirasa lebih baik seperti misalnya pada sisi dekor. Selain kualitas kemasan yang lebih baik, TV swasta juga memiliki kualitas pemancar yang lebih baik namun luas pemancar tidak sebanyak TVRI.

Hampir sama dengan analisis competitive analysis, Analisis pesaing (competitor analysis) dilakukan dengan melihat pesaing TVRI stasiun Jawa Barat yang diketahui adalah TV swasta lokal. Diketahui, TV swasta lokal seperti Bandung TV, PJTV, AKATV dirasa tidak lebih unggul dibandingkan dengan TVRI stasiun Jawa Barat. Hal ini dilihat dari konten, pemancar dan kejernihan layar yang dirasa lebih baik TVRI stasiun Jawa Barat.

Sebagai tambahan, aspek internal atau brand elements termasuk merek perusahaan sebelumnyapun perlu dianalisis. Dalam hal internal menurut (Juntunen, Saraniemi, \& Jussila, 2010), brand element atau internal aspects dapat dilihat melalui analisis SWOT. TVRI stasiun Jawa Barat memiliki kekuatan yaitu sumber daya manusia yang lebih berpengalaman, jangkauan lebih luas dengan
13 pemancar, status TVRI stasiun Jawa Barat sebagai TV publik sehingga lebih dipercaya masyarakat, memiliki program unggulan dan kuat dengan kearifan lokal serta tayangan yang didukung dengan 21 kontributor. Namun, adanya kekuatan juga tentu ada kelemahan. TVRI stasiun Jawa Barat memiliki kelemahan yaitu banyaknya karyawan yang sudah mendekati usia pensiun, pembiayaan TVRI stasiun Jawa Barat yang terbatas dan birokrasi yang rumit, kualitas layar yang masih SD dan audio yang masih mono, teknologi yang dimiliki terbatas, keterbatasan Kemampuan dan masih adanya karyawan TVRI stasiun Jawa Barat yang belum siap menghadapi persaingan membatasi ruang gerak televisi publik ini.

Pada dasarnya, kelemahan tersebut tidak membuat perusahaan tidak dapat dikembangkan karena kelemahan masih bisa diperbaiki dan tentu peluang untuk mengembangkan perusahaan masih tetap ada. Selain itu, Jangkauan TVRI stasiun Jawa Barat yang luas dapat membuat kerjasama dengan berbagai pihak sehingga peluang untuk memajukan perusahaan masih bisa dijangkau. Dalam hal ancaman atau threat, ancaman yang dirasakan TVRI stasiun Jawa Barat yaitu semakin menjamurnya televisi swasta, bergantinya selera masyarakat, masyarakat tidak punya lagi kebanggaan terhadap budayanya sendiri, bermunculannya media baru, tayangan TVRI 
stasiun Jawa Barat yang sama dengan TV swasta namun lebih diminati TV swasta harus siap untuk dihadapi oleh TVRI stasiun Jawa Barat.

"Kekuatan kita adalah jangkauan kita lebih luas dibandingkan swasta, punya kekuatan pasti punya kelemahan dan kelemahan kita adalah SDMnya, teknologi, dana, peluangnya karena jangkauan kita lebih luas jadi orang bisa bekerja sama, ingin mengisi acara juga oke karena lebih luas, ancamannya juga TV swasta dan media baru, teknologi kedepan semakin canggih kalau ingin memenangkan suatu persaingan ya penguasaan teknologi dan SDM karena ketika dua itu dikuasai kita bisa oke" (Sanif, 2019)

Setelah melalui analisis situasi dan analisis internal yang berupa analisis SWOT, langkah selanjutnya adalah menentukan keputusan yang akan diambil. Meskipun analisis tersebut tidak dilakukan secara teoritis namun analisis yang dilakukan sebelumnya secara tidak langsung dibuat setiap sebelum membuat keputusan. Menurut(Yogi, Ruchiat, \& Setianti, 2016) untuk mendapatkan hasil yang terbaik, pengambilan keputusan seharusnya mengikuti suatu tahapan yang sistematis dan terkendali. Hasil suatu proses pengambilan keputusan sangat dipengaruhi bagaimana tahapan proses tersebut dilakukan. Hasil keputusan tersebut adalah TVRI stasiun Jawa Barat tetap mengirimkan konten lokal yang dimiliki dalam acara Pesona Indonesia, Anak Indonesia, Inspirasi Indonesia untuk diakomodir TVRI pusat sebagai upaya menjadi world class broadcaster.
Keputusan lainnya yaitu membuat sebuah program siaran baru yang lebih mewakili millenial dan membuat sebuah program siaran baru anak yang mendidik. Tidak hanya melalui program siaran baru, TVRI juga memutuskan untuk perlu mengubah tampilan seperti pada logo dan slogan. Slogan tersebut berganti dari sobat urang sarerea menjadi media pemersatu bangsa untuk memperkuat identitas TVRI. TVRI juga diketahui membuat sebuah slogan yaitu \#kamikembali selama proses rebranding berlangsung sebagai ungkapan wajah baru TVRI. TVRI stasiun Jawa Barat juga memutuskan untuk memaksimalkan media digital agar lebih mengikuti perkembangan zaman. Hal ini juga dilakukan sebagai upaya memperkuat identitas menjadi media pemersatu bangsa dan world class broadcaster.

Tahap ketiga dari proses corporate rebranding adalah taha planning. Tahap planning yaitu sebuah tahap yang terdiri dari rencana-rencana yang dilakukan untuk membuat suatu perubahan. Tahap ini meliputi tahap akhir yang dibayangkan, tujuan dan visi dari perusahaan yang baru berdasarkan nilai perusahaan. Repositioning memiliki kata dasar yaitu positioning. Positioning adalah bagaimana sebuah produk, perusahaan, atau organisasi menempatkan dirinya sebagai sesuatu yang khas dan berbeda dari kompetitornya kepada publiknya. Dengan demikian, sebuah produk, 
perusahaan atau organisasi melakukan positioning bertujuan untuk menanamkan gambaran dan pengetahuan khusus tentang dirinya kepada publiknya, terutama gambaran dan pengetahua yang membedakan produk, perusahaan atau organisasi tersebut dengan para kompetitornya (Pramesti, Hafiar, \& Sani, 2017). Berdasarkan hasil wawancara, diketahui bahwa repositioning TVRI stasiun Jawa Barat yang ingin dicapai yaitu kembali lagi pada visi TVRI yakni menjadi media penyiaran kelas dunia dan media pemersatu bangsa.

Selain itu, repositioning ini juga mengacu pada permasalahan image TVRI sebelumnya yang lawas atau kuno sehingga TVRI kini ingin dipandang menjadi media yang lebih kekinian dan modern. Cara yang dilakukan TVRI stasiun Jawa Barat untuk mencapai repositioning tersebut adalah dengan membuat sebuah program acara yang tidak merusak martabat bangsa. Dalam merencanakan world class broadcaster tersebut, TVRI stasiun Jawa Barat tetap berperan dalam kearifan lokal. Upaya perencanaan repositioning tersebut dilakukan dengan melakukan tindak lanjut dari keputusan yang dilakukan dengan menentukan lokasi, tema, dan pembawa acara atau narasumber melalui pra-survei untuk dipilih dalam program acara Anak Indonesia, Inspirasi Indonesia, dan Pesona Indonesia setiap bulannya untuk diakomodir TVRI pusat menjadi world class broadcaster.

TVRI stasiun Jawa barat juga menentukan judul, arah atau tema program acara baru yang lebih mewakili millenial dalam mencapai image yang kekinian dan modern. Perencanaan tersebut mendapatkan hasil yakni judul program yang dinamai "Creative On Stage". Nama tersebut menyesuaikan dengan tema program yakni program dengan sebuah ajang tampil kreativitas kaum millenial. Hal yang perlu tetap diingat adalah lebih mewakili millenial disini bukan mengganti target audience dari TVRI itu sendiri, melainkan salah satu strategi untuk meningkatkan image yang kekinian dan modern . Selain Millenial, hal ini berlaku pula pada menindaklanjuti keputusan sebelumnya yaitu membuah sebuah program acara anak. Cara yang sama dilakukan yaitu dengan menentukan judul, tema, dan penyesuaian program acara yang kekinian dan modern dengan berdasarkan prinsip tontonan dan tuntunan. Hal ini menjadi pembeda TVRI dengan TV lainnya yang berdasarkan pemantuan KPI Terhadap tayangan telvisi pada tahun 2014, menemukan hanya $27 \%$ yang aman dari kekerasan, seks dan mistik sedangkan 73\% lainnya dinilai mengandung salah satu dari ketiga unsur tersebut (Gumiarto, Abdullah, \& Puspitasari, 2017). Hasil perencanaan tersebut diketahui bahwa program ini merupakan sebuah acara quiz anak-anak yang diberi judul "Be-Smart". 
Pemberian nama kembali (renaming) bagi perusahaan terkadang dilakukan untuk mengirim signal kepada pemilik kepentingan bahwa perusahaan sedang melakukan perubahan, baik dari strategi maupun kepemilikan perusahaan. Pada tahap ini perubahan juga terjadi pada slogan perusahaan. Dalam hal ini, TVRI melakukan nama deskriptif dengan pergantian slogan dari sobat urang sarerea menjadi media pemersatu bangsa untuk memperkuat identitas. Tindak lanjut dari keputusan sebelumnya ini dilakukan dengan merencanakan perubahan atribut perusahaan seperti ID card, alat tulis kantor, merchandise, souvenir dan lain-lain dengan slogan baru. Hal ini juga dilakukan melalui advertisement dan publikasi media sosial TVRI stasiun Jawa Barat, (Bantilan, Wulan, \& Pamungkas, 2017).

Aspek selanjutnya yaitu restrukturisasi, restrukturisasi dalam suatu organisasi ini dapat dilakukan melalui upaya manajemen dengan cara melakukan penataan ulang atau rekayasa ulang (reengineering) sehingga perusahaan dapat melakukan adaptasi terhadap pengaruh perubahan lingkungannya, sehingga perusahaan akan tetap bertahan hidup. Restuktrisasi merupakan bagian yang penting, tanpanya organisasi akan kehilangan kemampuan untuk bertahan. Dengan restukturisasi organisasi dapat menata ulang strukturnya sesuai dengan visi dan misi (Purdiaswasri, Rajardjo, \& Idris,
2016). Dalam hal ini, TVRI stasiun Jawa Barat tidak melakukan perubahan struktur karena yang ada hanyalah pergantian kepala stasiun. Hal ini juga tidak berkaitan dengan rebranding karena dilakukan secara umum dengan biasa dilakukan dalam 2 atau 3 tahun sekali.

Redesigning dilakukan pada semua elemen livery yang ada di organisasi seperti alat tulis, brosur, iklan, laporan tahunan, kantor, dan truk pengiriman, yang terlihat manifestasi dari posisi yang diinginkan perusahaan (Putri, Sumartias, \& Sjoraida, 2018). TVRI stasiun Jawa Barat merencanakan perubahan tampilan visual (redesigning) dengan menentukan perubahan tampilan apa saja yang perlu dilakukan. TVRI stasiun Jawa Barat merencanakan perubahan tampilan fisik logo seperti pada tampilan gedung yang lebih kekinian dan modern, perubahan tampilan media sosial yang sekaligus pula untuk memaksimalkan media digital, merencanakan perubahan tampilan baik dengan background studio yang disesuaikan kembali dengan kearifan lokal, telop maupun perubahan logo yang lebih kekinian dan modern pada tampilan tayangan televisi.

"Kita tentuin mana aja yang perlu diubah, yang sekiranya nongol di publik contohnya kop surat, amplop, id card, stempel, seragam, microphone, mobil, tampilan gedung, dsb karena kalau semuanya kita bikin juga kan terbatas dana" (Adityo, 2019).

Tahap keempat adalah preparing dimana 
mempersiapkan segala kebutuhan rebranding yang merujuk pada tahap sebelumnya, yaitu tahap perencanaan. Pada tahap preparing ini meliputi Preparing The Plans (Persiapan Rencana) dan pre-test for launching (Juntunen, Saraniemi, \& Jussila, 2010). Pada bagian paket acara Pesona Indonesia, Anak Indonesia dan Inspirasi Indonesia, hal yang dilakukan pada tahap ini yaitu dengan melakukan koordinasi bersama crew yang akan terlibat melalui penentuan editor, kameramen, penyiar, dsb. Selain itu, pada tahap persiapan, crew juga mempersiapkan peralatan yang akan digunakan.

Dalam pembuatan program baru yakni "Creative On Stage” dan "Be Smart" Untuk mencapai image yang kekinian dan modern, setelah menentukan perencanaan, selanjutnya adalah menghubungi pengisi acara dan penyiar yang sesuai dengan program tersebut. Tidak hanya disitu, Tim program juga berkoordinasi untuk mempersiapkan acara tersebut dengan crew yang terlibat misalnya untuk persiapan studio dan kerjasama dengan instansi terkait seperti pemerintah daerah dan lembaga les Neutron dalam pembuatan soal.

Persiapan yang dilakukan pada aspek redesigning dan renaming yang telah dilakukan sebelumnya juga ditindaklanjutkan dengan tim IT TVRI stasiun Jawa Barat. Tim inilah yang mengkaji ulang berupa studi literatur dengan berdasarkan analisis buku panduan identitas yang telah diberikan oleh TVRI pusat. Analisis

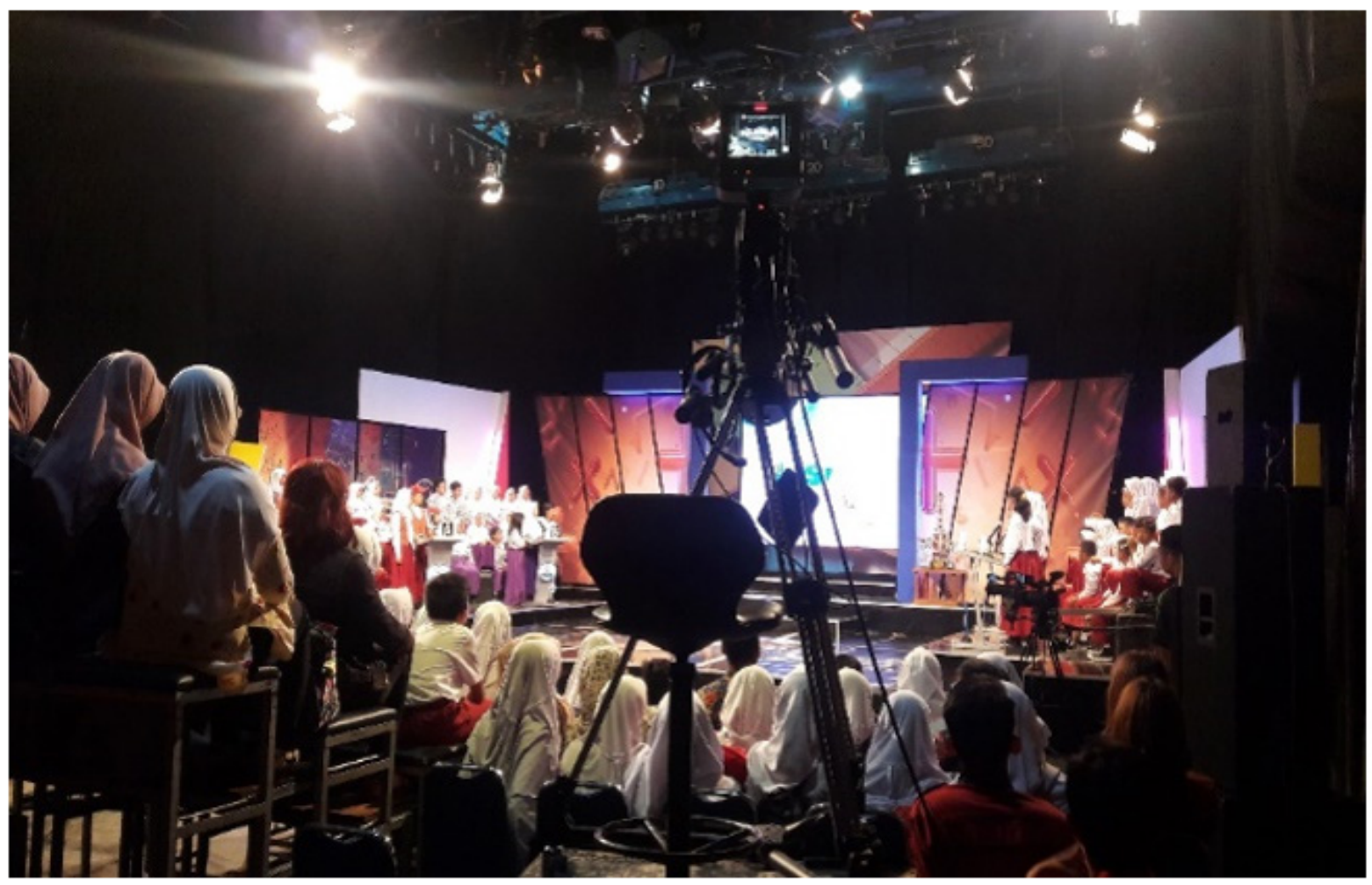

Sumber: hasil penelitian, 2019 
tersebut berlaku untuk semua perubahan tampilan baik tampilan media digital, logo, slogan, dsb.

"Dari on air sama off air sendiri itu sama misalnya fontnya sama, warna itu juga beda-beda kalau gak salah merah untuk olahraga, hijau untuk budaya, biru untuk berita, bulat besar di logo itu maksudnya menyambungkan TVRI ke dunia, kalau bulat kecil itu artinya acara TV sendiri, kalau warna ungu untuk hiburan, orange itu kalau gak salah juga hiburan. Kalau sebelum rebranding itu lebih bebas tergantung kita aja, kalau font kita kalau gasalah pakai Gottam." (Nusantara, 2019)

Hal yang dilakukan di atas berdasarkan hasil penelitian tersebut tentunya sesuai dengan konsep dan ungkapan triangulator yakni pada tahap ini preparing yang dimaksud adalah mempersiapkan kebutuhan dengan merujuk pada tahap sebelumnya yaitu planning. Dalam menghindari kegagalan saat launching, maka sebelumnya perlu dilakukan pre-test for launching yang dilakukan dengan melakukan test market. Namun, TVRI stasiun Jawa Barat belum melakukan pretest untuk launching (pre-test for launching) karena pre-test sendiri dilakukan oleh TVRI pusat. Namun, dalam hal ini TVRI stasiun Jawa Barat menyiapkan pre-launching sebuah teaser dan countdown termasuk penggunaan \#kamikembali pada sosial media untuk membuat masyarakat penasaran dengan launching TVRI stasiun Jawa Barat.

Launching adalah meng-komunikasi kan the new corporate brand kepada internal stakholders dan external stakeholders
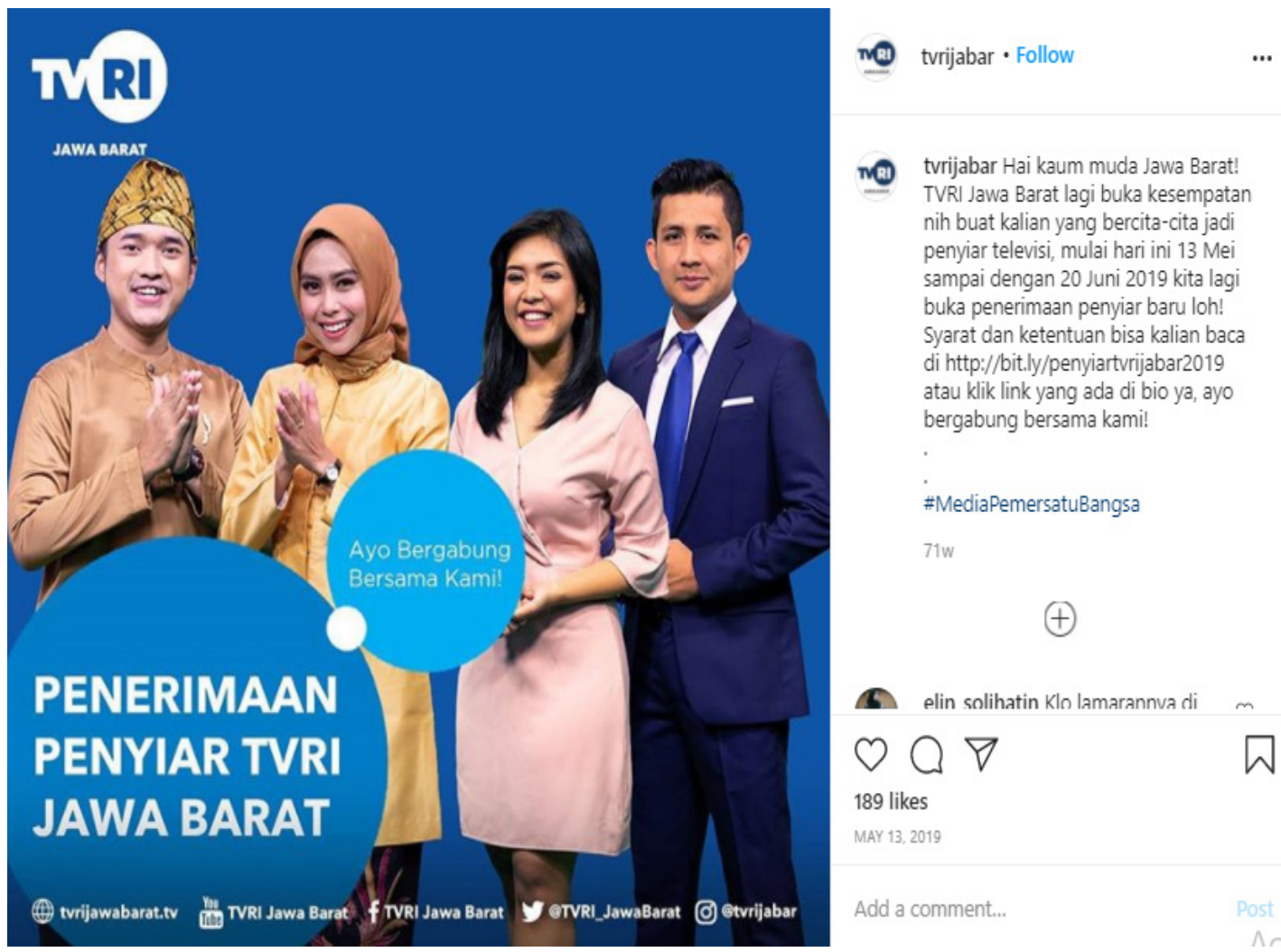

Sumber: akun instagram @tvrijabar, 2019

Gambar 2 Contoh penggunaan warna biru pada kategori informasi 


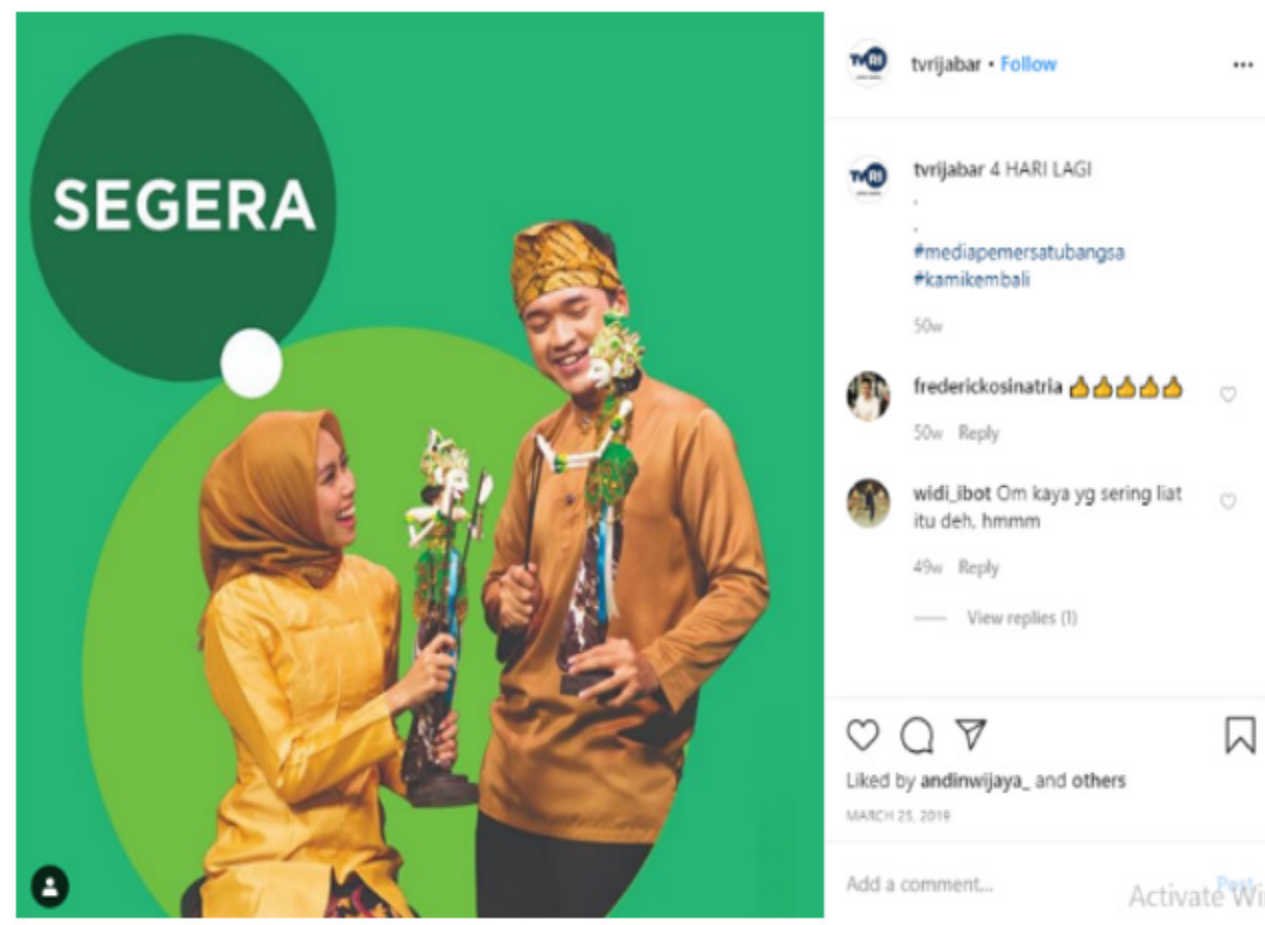

Sumber: Akun Instagram @tvrijabar, 2019

\section{Gambar 3 Salah satu contoh countdown TVRI stasiun Jawa Barat}

(Juntunen, Saraniemi, \& Jussila, 2010). TVRI stasiun Jawa Barat sudah melakukan launching yang sesuai dengan konsep Juntunen karena telah melakukannya secara intenal stakeholder maupun eksternal stakeholder. Selaras dengan konsep tersebut, TVRI stasiun Jawa Barat melakukan launching atau publikasi pada internal stakholders dengan melalui tim rebranding yang melakukan rapat internal lalu diteruskan kepada seluruh karyawan. Publikasi internal stakeholders ini juga dilakukan melalui buku panduan identitas dan majalah internal yang berikan TVRI pusat, penyebaran informasi rebranding dalam komunikasi non formalpun lebih sering kali dilakukan misalnya pada penyebaran informasi melalui media sosial seperti whatsapp group. Pergantian Id Card, atribut, perlengkapan kantor juga dilakukan untuk publikasi internal.

Pada external stakeholders, penyebaran informasi dilakukan melalui soft launching seperti kegiatan Citarum Harus dan Pemilu Damai yang sekaligus untuk merayangkan ulang tahun TVRI stasiun Jawa Barat. Dalam acara tersebut pula, TVRI stasiun Jawa barat melakukan kerjasama dengan media cetak, radio, pemerintah daerah dan pemangku kepentingan lainnya. Media promosi seperti banner, baligho, gedung, mobil dan tentunya media sosial juga dilakukan TVRI stasiun Jawa Barat untuk publikasi ekstenal stakeholders. TVRI stasiun Jawa Barat juga bekerjasama dengan komunitas pecinta TVRI Jabar serta menyelipkan informasi rebranding pada konten 
atau program acara yang ditayangkan.

Tahap ketujuh yaitu evaluasi. Mengevaluasi mencakup mengukur keberhasilan atau kegagalan proses. Pemantuan dan pelacakan reaksi secara berkala. Yang terbaik, evaluasi mencakup semua fase proses, sasaran tercapai, misalnya kesadaran diantara para pemangku kepentingan, survei pelanggan dan survei citra perusahaan juga merupakan cara untuk melakukannya dan mengevaluasi keberhasilan proses (Juntunen, Saraniemi, \& Jussila, 2010). Evaluasi perlu memerhatikan beberapa hal seperti awareness among stakeholders, customur surveys, dan corpoate image survey (Juntunen, Saraniemi, \& Jussila, 2010).

Brand awareness yaitu kemampuan sebuah produk akan merek untuk selalu ingat dalam ingatan konsumen saat konsumen memikirkan berbagai produk tertentu dan dengan mudah suatu merek akan muncul dalam ingatannya. Awareness among stakeholders disini adalah awareness yang dirasakan external stakeholders pada setiap strategi perusahaan yang dilakukan. Diketahui, tayangan paket acara seperti Anak Indonesia, Pesona Indonesia dan Inspirasi Indonesia untuk diakomodir TVRI pusat dirasa sudah baik karena lebih menonjolkan sektor wisata lokal dan budaya serta edukasi. Pengambilan gambar juga dikatakan sudah cukup baik. Namun, hal ini masih perlu perbaikan dalam pengambilan gambar dan sisi yang lebih menarik (Oktaviani \& Rustandi,

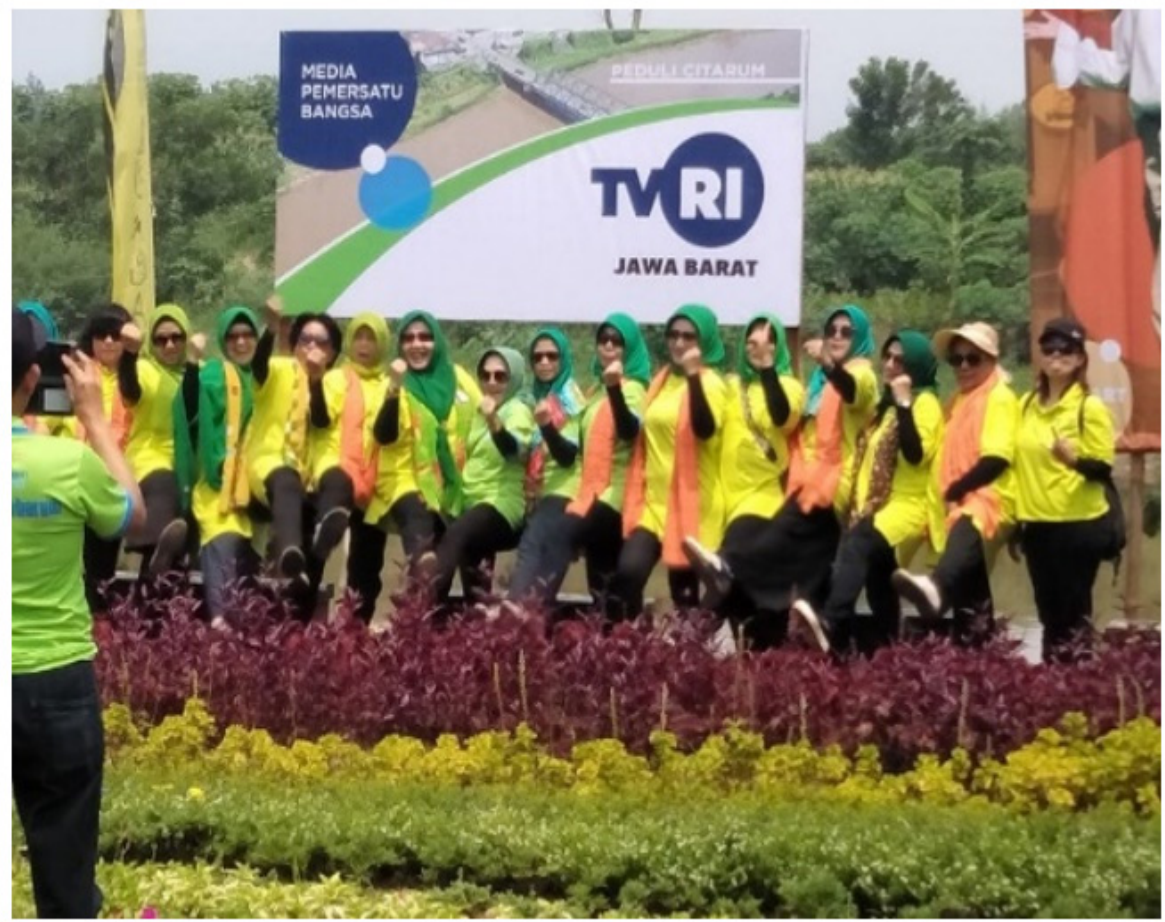

Sumber: Hasil penelitian, 2019

Gambar 4 Soft launching rebranding pada acara Citarum Harum 
2018).

Pada program Creative On stage dan Be Smart, publikasi yang dilakukan TVRI stasiun Jawa Barat dirasa belum maksimal. Sehingga awareness among stakholders pada program ini dan mewakili millenial untuk lebih kekinian dan modern serta mengembalikkan minat tontonan masyarakat masih dirasa kurang dan perlu perbaikan. Pada perubahan tampilan, stakeholders atau dalam hal ini seluruh triangulator yaitu komunitas pecinta TVRI Jawa Barat dan customers mengapresiasi dengan perubahan tampilan yang dilakukan. TVRI stasiun Jawa Barat juga masih perlu mengoptimalkan publikasi yang dilakukan melalui media digital.

Selain awareness among stakeholders, peneliti juga melakukan wawancara mengenai customer surveys pada setiap strategi yang dijalankan. Setelah strategi rebranding telah diimplementasikan, selanjutnya adalah bagaimana upaya TVRI stasiun Jawa Barat melakukan evaluasi terhadap strategi yang dilakukan. Menurut Juntunen, evaluasi ini penting dilakukan dengan mempertimbangkan setiap strategi atau keputusan yang dilakukan sebelumnya. Pada pengiriman paket acara Pesona Indonesia, Anak Indonesia dan Inspirasi Indonesia untuk diakomodir TVRI pusat, pengirman tersebut belum mencapai tujuan yang diharapkan.
TVRI stasiun Jawa Barat belum melakukan evaluasi internal secara menyeluruh. Namun, hal ini dilihat berdasarkan complain yang diterima dan selama ini TVRI belum pernah mendapatkan complain sehingga bisa dapat dikatakan sukses. Tetapi, program siaran mewakili millenial sendiri dirasa belum mewakili millenial sehingga belum dirasakan kekinian dan modern. Dalam media digital TVRI stasiun Jawa Barat merasa masih perlu untuk melakukan evaluasi misalnya pada tayangan yang masih diupload seluruhnya pada platform youtube. Hal ini tentunya menjadi bahan evaluasi untuk memaksimalkan media digital. Namun untuk perubahan tampilan media sosial dirasa sudah sesuai. Pada perubahan tampilan, TVRI stasiun Jawa Barat sudah melakukan perubahan tampilan visual yang diinstruksikan pusat. Perubahan tampilan tersebut diakui tidak memiliki masalah dan menimbulkan dampak positif seperti bertambahnya spirit dan semangat baru karyawan TVRI stasiun Jawa Barat. Hal inilah yang mengindikasikan bahwa memperkuat identitas menjadi media pemersatu bangsa dalam hal tampilan dirasa telah sukses. "Evaluasi rebranding sendiri hanya melalui siaran, dipantau setiap hari dan tidak boleh ada yang salah sampai ke promo on air atau offpun kita sudah ada aturannya, pernah kita ada yang salah waktu itu kita upload di medsos tapi seharusnya berbeda dengan on air biasa terus kita ditegur gaboleh lagi gitu tapi kalau tampilan sendiri udah sesuai sama instruksi pusat" (Herman, 2019). 
Pengertian citra adalah absrak (intangible) dan tidak dapat diukur secara sistematis, tetapi wujudnya bisa dirasakan dari hasil penilaian baik atau buruk TVRI stasiun Jawa Barat (Latifa \& Setiawan, 2019). Corporate image surveys berdasarkan survei nielson dan didapatkanlah hasil bahwa TVRI Stasiun Jawa Barat mengalami peningkatan dengan masuk menjadi 10 besar dalam audience share yang sebelum rebranding belum pernah masuk dalam 8 besar. Selain itu, berdasarkan survei hasil indeks KPI, TVRI stasiun Jawa Barat unggul dalam program informasi, berita, religi dan anak. Namun, TVRI masih memiliki kelemahan pada program acara hiburan.

Continuing adalah fase terakhir dari proses rebranding. Kelanjutan proses, semua masalah untuk fase ditemukan melalui kasus. Dalam hal ini, customers melihat kualitas operasi perusahaan termasuk dalam hal kualitas layanan dan janji yang diberikan oleh perusahaan. Menurut customers sendiri, TVRI stasiun Jawa Barat dirasa masih perlu meningkatkan kualitas tayangan yang masih dirasa lawas atau kuno terutama pada program hiburan. Namun, untuk perubahan tampilan para customers mengapresiasi perubahan tampilan yang dilakukan. Hal ini mengindikasikan bahwa TVRI stasiun Jawa Barat berhasil meningkat image menjadi kekinian dan modern dalam perubahan tampilan, hanya saja TVRI stasiun
Jawa Barat perlu lebih memerhatikan konten acara terutama pada program acara hiburan.

Aspek kedua dalam tahap continuing adalah for personnel. Personnel disini adalah orientasi dari kelanjutan sistem kerja dan pendidikan yang ditawarkan kepada karyawannya. Dalam Mengukur keberhasilan kinerja karyawan merasa sulit dan tidak bisa melakukan pengukuran keberhasilan karena tidak memiliki data yang jelas. Namun, TVRI stasiun Jawa Barat merasa memiliki perubahan semangat kerja dan motivasi yang lebih meningkat dibandingkan sebelumnya. Akan tetapi, peningkatan semangat kerja tersebut tidak dibarengi dengan pelatihan, workshop ataupun edukasi lainnya yang dapat meningkatkan kemampuan dan motivasi kinerja karyawan.

Aspek terakhir adalah for management and personnel. Hal ini termasuk dalam pertimbangan lanjutan dari strategi brand perusahaan yang dilakukan. Pada pengiriman konten Pesona Indonesia, Anak Indonesia dan Inspirasi Indonesia, TVRI stasiun Jawa Barat tetap melakukan pembuatan dan pengiriman tersebut meskipun memiliki masalah pada tahap evaluasi. Selanjutnya, kelanjutan dari program Creative On Stage adalah program tersebut dihentikan atau tidak dilanjutkan semenjak oktober 2019. Hal tersebut dikarenakan masa tayang yang telah usai dan strategi untuk lebih mewakili millenial pada tahap evaluasi dirasa 
masih belum tercapai. Dengan diberhentikannya program acara baru yang lebih mewakili milenial, TVRI stasiun Jawa Barat memutuskan untuk kembali berfokus pada seni dan budaya.

Pada program Be-Smart, program tersebut masih berlanjut karena dirasa tidak memiliki masalah. Berdasarkan survei indeks KPI, TVRI stasiun Jawa Barat juga unggul dalam kualitas bidang program acara anak. Pada perubahan tampilan, TVRI stasiun Jawa Barat tetap menggunakan logo, slogan yang telah ditentukan sebelumnya hal tersebut karena perubahan tampilan ini memberikan dampak yang positif seperti meningkatkan semangat kerja karyawan dan dirasa diapresiasi banyak pihak. Pada memaksimalkan media digital, TVRI stasiun Jawa Barat masih menentukan evaluasi dan belum melakukan perubahan apapun pada media digital selain perubahan tampilan.

\section{SIMPULAN}

Proses corporate rebranding LPP TVRI stasiun Jawa Barat diawali dengan mempelajari triggering yakni mengidentifikasi dan mengatasi penyebabnya yang mengarah pada alasan untuk mengubah citra. Dalam mengidentifikasi triggering, TVRI melaluinya tanpa melakukan change in ownership structure serta diversifikasi maupun divestment pada corporate strategy. TVRI stasiun Jawa Barat hingga kini masih berstatus TV publik berdasarkan UU nomor 32 tahun 2002. Rebranding ini didasari dengan corporate strategy yang dimiliki yakni menuju world class broadcester, competitive position seperti permasalahan pada audience share, image dan identitas yang berbeda-beda pada masing-masing TVRI daerah serta external environment yakni TV publik yang dirasa telah ditinggalkan oleh masyarakat dan perkembangan media digital atau tuntutan zaman. faktor-faktor triggering atau pemicu tersebut didukung oleh keputusan pusat yakni wewenang direksi dan pengawas untuk dilakukannya rebranding TVRI seluruh stasiun daerah termasuk TVRI stasiun Jawa Barat.

Pada Tahap kedua yaitu analyzing and decision making, TVRI stasiun Jawa Barat sudah menganalisis dan membuat keputusan mencakup menganalisis situasi saat ini. Analisis tersebut terdiri dari market analysis dengan melakukan kerjasama penelitian serta mengacu pada teori kedekatan, competitive analysis, competitor analysis, dan internal aspects dengan menggunakan analisis SWOT yang tentunya setelah analisis tersebut juga melakukan sebuah pembuatan keputusan. Pada Tahap ketiga yaitu planning adalah sebuah tahap yang terdiri dari rencana yang dilakukan untuk membuat suatu perubahan. Planning yang dilakukan sudah sesuai dengan mengacu tujuan awal. TVRI stasiun Jawa Barat sudah melakukan 
repositioning, renaming dan redesigning.

Namun, hal yang belum melakukan dilakukan adalah restructuring, dengan hanya melakukan pergantian kepala stasiun yang rutin dilakukan 2/3 tahun sekali. Hal ini tentu menjadi bahan evaluasi pada restructuring, mengingat TVRI sendiri memiliki permasalahan pada sumber daya manusia (SDM).

Pada Tahap preparing, Hal yang dilakukan yaitu mempersiapkan kebutuhan rebranding dengan merujuk pada tahap sebelumnya, yaitu tahap perencanaan. Dalam preparing the plans, TVRI stasiun Jawa Barat sudah melakukan persiapan yang mengacu pada perencanaan sebelumnya. Namun, aspek yang belum dilakukan pada tahap ini adalah pretest for launching dengan hanya melakukan pre-launching. Pre-test for launching sendiri dilakukan oleh TVRI pusat, namun hal ini juga dapat menjadi evaluasi tersendiri untuk melakukan pre-test pada masing-masing TVRI daerah. Pada tahap selanjutnya yaitu Launching adalah tentang mengkomunikasikan the new corporate brand terlebih dahulu kepada internal stakeholders dan setelah itu kepada external stakeholders. TVRI stasiun Jawa Barat sudah memerhartikan launching atau publikasi melalui internal stakeholders maupun external stakeholders.

Pada tahap evaluating yaitu mencakup semua fase proses dan sasaran yang ingin dicapai.
TVRI stasiun Jawa Barat belum melakukan evaluasi rebranding secara keseluruhan. Pada customer surveys, evaluasi ini dilihat dari kritik atau respon masyarakat. Namun, pada dasarnya, customer surveys ini dilihat pada setiap keputusan yang dilakukan. Setelah melakukan analisis dan pembuatan keputusan, dalam corporate image Surveys, TVRI stasiun Jawa Barat melihat dari survei hasil nielson dan survei indeks KPI. Continuing adalah fase terakhir dari proses rebranding. TVRI stasiun Jawa Barat sudah mempertimbangkan kelanjutan beberapa program berdasarkan hasil evaluasi pada aspek management for personnel. Namun, beberapa program lainnya masih ada yang belum sesuai dengan kelanjutan dari evaluasi yang dilakukan. Pada for personnel, TVRI stasiun Jawa Barat juga belum dapat mengukur kinerja karyawan secara data jelas dan belum menawarkan pelatihan atau pendidikan kepada karyawannya.

\section{DAFTAR PUSTAKA}

Adityo, I. (2019, Desember 5). Wawancara langsung proses corporate rebranding TVRI stasiun Jawa Barat. (H. Regitadika, Pewawancara)

Aprilia, P., Hafiar, H., \& Subekti, P. (2020). Fungsi public relations pada strategi merek Inspira TV dalam membangun brand perusahaan. ProTvF: Jurnal Kajian Televisi dan Film, 4(1), 20-41. doi:10.24198/ptvf. $\mathrm{v} 4 \mathrm{i} 1.24032$ 
Bantilan, D. S., Wulan, R. R., \& Pamungkas, I. N. (2017). Strategi rebranding Zora Radio. PRofesi Humas, 2(1), 1-12. doi:doi. org/10.24198/prh.v2i1

Franita, R. (2018). Mekanisme good corporate governance dan nilai perusahaan: studi untuk perusahaan telekomunikasi. Medan: Lembaga Penelitian dan Penulisan Ilmiah Aqli.

Gumiarto, I., Abdullah, A., \& Puspitasari, L. (2017). Kajian kritis tayangan televisi favorit kelas menengah perkotaan. ProTvF: Jurnal Kajian Televisi dan Film, 1(1), 1329. doi:10.24198/ptvf.v1i1.13329

Herman. (2019, Desember 9). Wawancara langsung proses corporate rebranding TVRI stasiun Jawa Barat.

Herman. (2019, Desember 6). Wawancara Pra Survei. (H. Regitadika, Pewawancara)

Juntunen, M., Saraniemi, S., \& Jussila, R. (2010). Corporate re-branding as a process. Semantic Scholar.

Kotler, P., \& Keller, K. L. (2009). Manajemen pemasaran jilid I. Jakarta: Erlangga.

Kurniawa, P., \& Budhi, M. K. (2017). Smart leadership being a decision maker. Yogyakarta: Andi.

Latifa, A., \& Setiawan, B. (2019). Strategi public relations radio Geronimo Yogyakarta dalam mempertahankan citra perusahaan. MediaTor, 12(2), 189-198. doi:10.29313/ mediator.v12i2

Madura, J. (2007). Pengantar bisnis edisi 4. Jakarta: Salemba Empat.

Masduki. (2017). Public broadcasting reform in the transitional society: the case of Indonesia. Jurnal Komunikasi Indonesia, 4(2), 112-118. doi:https://doi/org/10.7454/ jki.v6i2.8916

Nielson Indonesia. (2017, July 27). Penetrasi televisi masih yang tertinggi. Diambil kembali dari databoks.katadata. co.id: https://databoks.katadata.co.id/ datapublish/2017/07/27/penetrasi-televisimasih-yang-tertinggi

Noor, J. (2016). Metodologi penelitian: skripsi, tesis, disertasi \& karya Ilmiah. Jakarta: Prenada Media Group.

Nusantara, J. J. (2019, Desember 16). Wawancara langsung proses corporate rebranding TVRI stasiun Jawa Barat. (H. Regitadika, Pewawancara)

Oktaviani, F., \& Rustandi, D. (2018). Implementasi digital marketing dalam membangun brand awareness. PRofesi Humas, 3(1), 1-20. doi:10.24198/prh. v3i1.15878

Panuju, R. (2017). Sistem penyiaran Indonesia: sebuah kajian strukturalisme fungsional. Jakarta: Kencana.

Pramesti, J., Hafiar, H., \& Sani, A. (2017). Langkah bisnis Trans Studio Mall Bandung dalammelakukan repositioning. Jurnal Ilmu Komunikasi, 7(1), 11-27. Diambil kembali dari https://jkms.ejournal.unri.ac.id/index. php/JKMS/article/view/3639/3539

Purdiaswasri, C., Rajardjo, S. T., \& Idris. (2016). Analisis restukturisasi: penerapan debirokratisasi PT. PLN (persero) Jawa Tengah dan DI. Yogyakarta. Jurnal Bisnis Strategi, 25(1), 82-95. Diakses dari https:// ejournal.undip.ac.id/index.php/jbs/search/ $\mathrm{h}$ ? simpleQuery=analisis + restrukturisasi\&s earchField=query

Putra, A. J. (2018, April 2). TVRI mati suri sejak ada TV swasta keluarga Soeharto. (D. H. Wirdhana, Pewawancara)

Putri, F. A., Sumartias, S., \& Sjoraida, D. F. (2018). Proses rebranding Mal Grand Indonesia oleh Departemen Marketing Communication PT Grand Indonesia. PRofesi Humas, 2(2), 102-118. 
doi:10.24198/prh.v2i2.9063

Sanif, M. (2019, Desember 16). Wawancara proses corporate rebranding TVRI stasiun Jawa Barat. (H. Regitadika, Pewawancara)

Setiawan, C. R. (2010). Metode Penelitian Kualitatif. Jakarta: Grasindo.

Sholihat, Y., Perbawasari, S., \& Lukman, S. (2018). Proses corporate rebranding PJTV Bandung menjadi SKTV. ProTvF: Jurnal Kajian Televisi dan Film, 2(2), 173-190. doi:10.24198/ptvf.v2i2.20823

Sugiyono. (2010). Metode penelitian kuantitatif kualitatif dan $R \& D$. Jakarta: Alfabeta.

Utami, S. P., Dida, S., \& Prastowo, F. A. (2017).
Strategi perencanaan public relations NET.TV dalam membentuk citranya sebagai televisi masa kini. ProTvF: Jurnal Kajian Televisi dan Film, 1(1), 61-76. doi:10.24198/ptvf.v1i1.13334

Vincent, E. I. (2016). International broadcasting as a tool of international diplomacy. New Media and Mass Communication, 46, 4552.

Yogi, G. P., Ruchiat, A., \& Setianti, Y. (2016). Emergency response plan Garuda Indonesia. PRofesi Humas-Jurnal Ilmiah Program Studi Hubungan Masyarakat, 1(1), 65-77. doi:10.24198/prh.v1i1.8537 